\title{
The Patterns and Trends of Environmental Conflicts in the Niger Delta: A Community Approach
}

\author{
Gbenemene Kpae, Eric \\ Adishi \\ benkpae@hotmail.com
}

\begin{abstract}
The negative impact of oil exploration on the Niger Delta environment cannot be overemphasized. Majority of the damage to the environment are due to oil spill and gas flares. Oil spills are due to corrosive and expired pipelines, while others are due to third party involvement. Apart from oil spills, gas flares has also been very destructive to the environment as toxic gas are released into the atmosphere daily. This gas flares causes breathing problems to inhabitants of local communities of the Niger Delta area. This research examines the patterns, trends, drivers and dynamics of conflict over environmental degradation in the Niger Delta. The study also determines existing mechanism for management of conflict over oil spills and gas flares in two selected communities: Bodo and K-Dere in Rivers State. We adopted a qualitative research design, and relied on primary and secondary sources of data. We found that oil spills and gas flares were the cause of conflict between the oil prospective companies especially Shell and oil bearing communities.
\end{abstract}

Keywords: Trend, Environmental conflict, Niger Delta, Community

\section{INTRODUCTION}

Oil is the mainstay of the Nigerian economy since Nigeria derives its foreign earning from the sale of oil and gas. And since oil was discovered in commercial quantity in the Niger Delta in the mid and late 1950s, millions of barrels of crude oil have been extracted from the region, and billions of U.S dollars have been derived from sales of crude oil. However, despite the enormous amount derived from the sale of crude oil and its contribution to the GDP of Nigeria, oil bearing communities are still underdeveloped and continue to suffer the impact of oil exploration. This situation creates feeling of frustration and anger among community members. Poverty and high rate of unemployment have created a huge network of criminal gangs who engage in illegal oil activities such as pipeline vandalisation in order to survive.

Since oil operation started in Ogoni land in the late 1950s more than 2000 barrels of oil have been spilled into the rivers and creeks thereby destroy the entire environment and livelihood of the people of the area, According to Amnesty International, it takes Shell between seven to two hundred days to respond to oil spills. Majority of the oil spill are due to outdated pipes, while Shell, on the other hand, and attributes the cause of spill to sabotage. Nonetheless, the producing communities bear the adverse effect of oil spills because it destroys their sources of sustenance and livelihood. Recently, as the issue of remediation of impacted site has began by Shell in Bo as part of its peace agreement with that community, one will expect that the conflict between Shell with its host communities will decrease, however rather than declining it seems to be increasing due to the poor perception of the people of the oil giant.

\section{OBjectives of THE STUdy}

The study was set out to achieve the following objectives:

1. To examine the patterns, trends, drivers and dynamics of conflicts over environmental degradation in Gokana LGA. 
2. To examine the impacted and competing groups and their interests.

3. To examine existing and emerging mechanisms for management of oils and gas flares among competing users in Gokana LGA.

4. To examine specific roles of women and girls in the conflicts and environmental degradation.

\section{METHODOLOGY}

The Purposive Sampling Techniques was used to select the two communities (K-Dere and Bodo) in which this study was carried out. The same technique was used to select the participants for this study. The Focus Group Discussions (FGD) and Key Informant Interviews (KII) were used to collect relevant data from respondents. The FGD was used to collect information from groups especially the women and youth groups including the fishermen association who were very conversant with the issue being studied, while the KII were data obtained from stakeholders in the community such as the paramount ruler, women leader, religious leader and other key members of the council of chiefs. Secondary data was collected from journals, books, magazines and news paper publications.

\section{REVIEW OF LITERATURE}

Adesina (2012) believes that gas flaring that is unethical has contributed significantly to the environmental degradation of the Niger Delta environment. Eragha and Irughe (2009) in Adesina (2012) also contend that gas flaring have altered the vegetation of the area by replacing natural vegetation with stubborn with stubborn grasses which makes the soil infertile and unproductive. Apart from the infertility of soil, Eragha and Irughe believe that gas flares has led to loss in biodiversity, with forest and economic crops being destroyed. Uyigue and Agho (2007) also confirmed this fact in Ayuba (2012) that the unsustainable oil exploration and exploitation activities in the Niger Delta has made the region one of the five most severely damaged ecosystems in the world. Ayuba also stressed that the concentration of acid rain water was much higher in the Niger Delta compared to other regions of the country. Again, gas flaring generates serious heat that destroys vegetations around flaring areas and destroys mangrove swamps and salt marshes, and suppresses the growth and flowing of some plants. Gas flaring is also associated with methane and carbon dioxide (CO2), which are greenhouse gasses responsible for climate change. Udok and Akpan (2017) note that gas flaring due to oil exploration by oil multinationals in the Niger Delta was generating more greenhouse gasses than the combined emissions of the rest of sub-Saharan Africa. Asuoka et al (2016) also added that gas flared in Nigeria by oil companies was estimated to be about a quarter or 30 percent of annual US and EU gas consumption level. K-Dere and Bodo are two communities in Ogoni that have suffered the adverse consequences of oil pollution and crude oil exploration and associated gas flaring for decades until in the early 1990s when oil exploration ceased in Ogoni; however their impact is still felt in Ogoni till date. It is imperative to shed some light on the region and the communities in which this research was conducted.

\section{The Niger Delta}

The Niger Delta covers a total land mass of 29,000 square Kilometers, that is, about 32 percent of the total land area of Nigeria. It is also the location of oil installations that lies mostly in the creeks. It is comprised of nine states that include Rivers, Cross River, Akwa Ibom, Delta, Bayelsa, Abia, Edo, Imo and Ondo. Initially, the area called Niger Delta had consisted of only three states namely, Rivers, Bayelsa and Delta states, however in 2000 they were expanded by President Obasanjo to include other states in the south east and south west due to their having substantial oil deposits (Dudafa, 2017). As a result, the land mass of the region has been expanded. According to the federal government, the Niger Delta region extends to over 70,000 kilometers and thereby contributing to $7.5 \%$ of the total land mass of Nigeria. The area also has a population estimate of over 30 million with diverse ethnic nationalities with fishing and farming as their main source of livelihood (Okonta, 
and Douglas, 2003). The ethnic groups inhabiting the Niger Delta region include Ijaws, Ogonis, Edo, Kwale-Igbo, Ibibio, Andoni, Igbo, Ikwerre, Urhobo, Ishekeri, Isoko, Efik, Etche, etc. The region became occupied by these diverse ethnic groups due to slave trade that brought about expanded social and economic activities involving huge migration and interaction between various ethnic groupings in the region (Nkejiaka, 2010). The Niger Delta is also the third largest drainage area of Africa's rivers, and also serves as a large low-lying land in the south east of Nigeria and having huge deposits of crude oil which flows from River Niger and River Benue. Since our research was carried out into K-Dere and Bodo communities in Ogoni, it will be imperative to give some brief background on them.

\section{Bodo Community}

Bodo is the largest community in Gokana local Government area of Rivers State. It lies at the extreme end of Gokana, and has a total population of about 69,000 people (according to 2005 census) both male and female. Bodo is also known as Tagba Pia Gokana (meaning the last born child of Gokana). The primary occupation of the people is fishing and farming. They also have huge deposit of oil and gas.

\section{Kegbara Dere (K-Dere) Community}

K-Dere has a total population of more than 40,000 people and endowed with a lot of crude oil reserves. In fact, K-Dere accounts for 54 out of the 96 oil wells in Ogoniland. It also has one manifold that is known as the Bomu Manifold and Bomu flow station. The community is accessible on both land and water. It is bounded on the west by Biara and Kpor, and on the North by Bodo, and on the East by Goi and Kira in Tai Local Government Area. Their prominent occupation is fishing and farming. Oil was struck in K-Dere in 1957, and since then several barrels of crude oil including gas have been exploited from the community. Despite these abundant natural resources, the community, just like other Ogoni communities, has nothing to show in terms of infrastructural development.

\section{Environment and Conflict}

There are several causes of environmental conflict in the Niger Detla. Some of them may be due to environmental pollution as a result of oil activities, while others may be caused by man's activities that are detrimental to the environment. Bob and Bronkhorst (2010) assert that the causes of environmental conflict vary across the globe and their manifestations differ considerably. Bob and Bronkhorst posit that the focus on environment and conflict alludes to the myriad of influence that human beings exert over the earth's natural resource-base and processes and the way in which natural events and environmental protection can affect human life. They maintained that there is a growing consensus among academia and policy makers that people are exerting increasing control over the natural environment with a range of adverse consequences. Similarly, Atkins (2014) notes that environmental degradation and scarcity have been identified by scholars as two major causes of conflict. Furthermore, Homer Dixon et al (2013) recognized the connection between environmental change and conflict

\section{Theoretical Review}

The Marxian conflict theory and the Frustration Aggression theory are used to analyze the patterns and trend of environmental conflict in the Niger Delta. Marx is of the view that society is in a state of perpetual conflict due to competition over scarce resources. Theory holds social order is maintained by domination and power rather than consensus and conformity, As a consequence, the wealthy in society try to hold on to power by any means possible, chiefly by suppressing the poor and powerless. Marx also assumes that the struggle to control the resources or common wealth of nations will always be a function of a strategy applied to dominate the process rather than by consensus. This situation creates class system and perpetual rivalry or conflict because those who dominate and monopolize the resources, at the expense of the greater majority want the status quo to continue. However, Marx believes the monopoly of the dominant class (bourgeoisie) shall be overthrown by the dominated class (proletariat) in their power inter-play. 
When the Marxian theory is related to the situation in the Niger Delta, it presupposes that when people feel deprived from getting what they deserve or they feel neglected, then frustration sets in which in turn creates conflict. Marx will analyze the situation in the Niger Delta that the government and the oil companies (bourgeoisie) have dominated and monopolized the system at the expense of the people of Bomu and Bodo. Thus there seems to be collaboration between the Nigerian government and the oil company to main their gains from the oil bearing communities, while caring less on the environmental pollution and degradation caused to the area.

The bourgeoisie in Nigeria, that is, the government and the oil multinationals including their local collaborators such as the chiefs and politicians connive together to deprive the people of Bomu and Bodo, majority of whom are poor, from getting what they deserve. This situation is further compounded with the damage caused to their environment by activities of oil multinationals that are quick to shift blame on the communities in order to avoid paying compensation. This situation breeds conflict between the community and the oil companies. Barry (2012), for instance, compared environmental pollution to environmental injustice. He believes environmental injustice is the deliberate targeting of disadvantaged populations and the disproportionate distribution of toxic substances and hazardous materials into their communities

\section{DiscusSiON OF FINDINGS}

This study investigated the patterns, trend, drivers and dynamics of conflict relating to environmental degradation in K-Dere and Bodo communities. The study also examined the mechanisms for management of conflicts relating to oil spills and gas flares in K-Dere and Bodo communities. Additionally, the study ascertains the specific roles of women and girls in the conflicts and environmental degradation on them. We found that oil spills is a major problem in the two communities that are the focus of this research, K-Dere and Bodo. Majority of the participants are of the opinion that oil spill is a major problem to their communities because it is a threat to their source of livelihood. In K-Dere, for instance, our participants say that oil spill is a major problem to their community, and occurs frequently. When it occurs, its level is very difficult to measure and damage caused is very difficult to quantify. However, in Bodo community, the spills occur regularly like in K-Dere, and the levels are very high and cause great devastation to the environment. The picture below shows an oil spill that occurred in Bodo on June 19, 2013 in which there was a rupture in the Trans Niger Pipeline (TPN) managed by Shell that carries about 150,000 barrels of crude oil daily to Bonny (Azuakola, 2013). As a result of the spill, several barrel of crude oil was spilled into the river, creeks, mangroves and farmlands, thereby destroying the environment and the main sources of livelihood of the people.

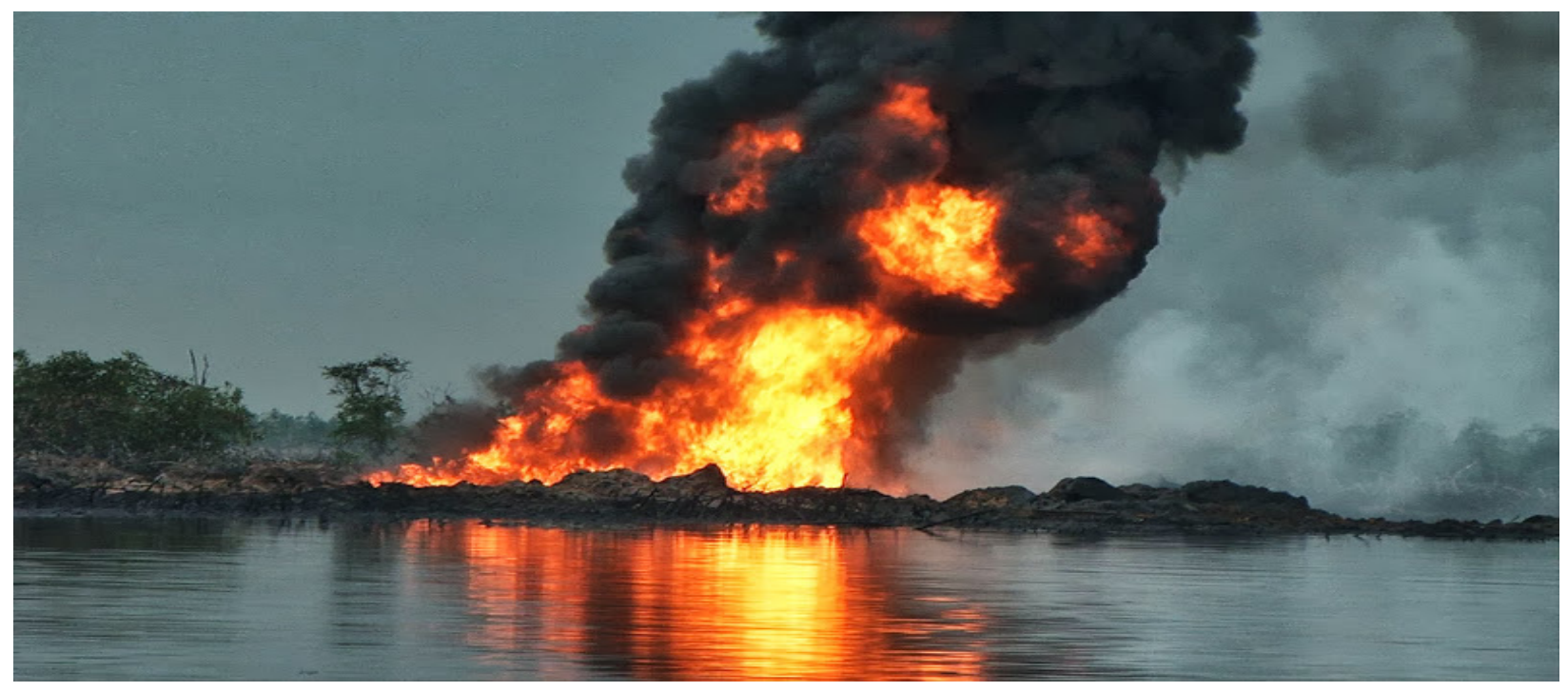

American Research Journal of Humanities and Social Sciences

Page 4 
The Patterns and Trends of Environmental Conflicts in the Niger Delta: A Community Approach

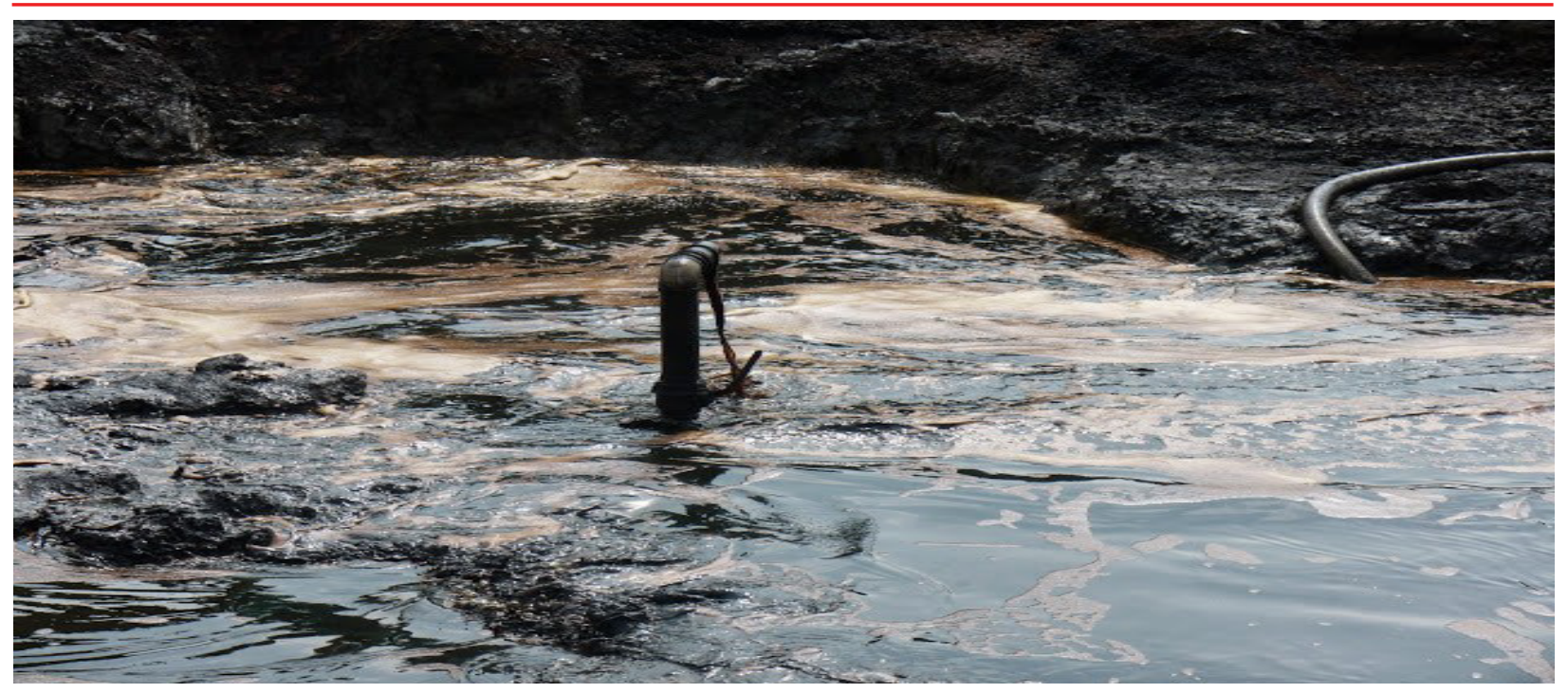

Pictorial view of the oil Spill that occurred in Bodo on June 19, 2013

It is important to stress that, although our research objective was framed in such a way as to determine the impact of oil spills and gas flares on target communities, but our findings show otherwise. Although oil spill has been a problem to K-Dere and Bodo communities, but gas flares has ceased in Ogoniland since 1993/1994 when MOSOP started its campaign against gas flaring. Despite that gas is no longer flared their impact, due to several decades of flaring, is still felt in the communities. Apart from the 2013 oil spill, Bodo community also experienced major oil spills in 2008 and 2009 respectively. Although the month when these spills occurred remains disputed but the years of occurrence remains the same (The True Tragedy, 2011). In a similar report compiled by United Nations Environmental Protection (UNEP), it documented the extent of pollution and environmental degradation due to oil spills in K-Dere oil field, manifold (flow station) also known as the Bomu oil field from 1969-2010. For instance, an oil spill that occurred in K-Dere between 1970 and 1971 was compared to a 'volcanic eruption' due to its impact because it lasted several weeks before it was brought under control. Additionally, the study found that negligence and equipment/operational failures are the fundamental cause of oil spills in K-Dere and Bodo communities. Our participants claimed that equipment failure was the major cause of oil spill. This position is further collaborated by the Amnesty International Report on the oil spill in Bodo and UNEP report where they attributed the cause of oil spill incidents to equipment failure (The True Tragedy, 2011). We found, however, that although some oil spills are due to human factors, overwhelming majority of them are due Shell's negligence and equipment failure.

The pipelines, most of which are buried on the surface of the ground are long overdue for replacement. According to a U.S diplomatic cable published by Willinks in 2008, it stated that 73 percents of oil pipelines in the Niger Delta are more than a decade overdue for replacement. The cable noted, "In many cases, the pipelines with a technical life of 15 years are still in use thirty years after installation". The cable continued, "Because the equipment is corroded, and relatively close to the surface making it more vulnerable to intentional and unintentional damage from natural human causes. Spills occur daily, and it often takes hours to find location of the spill and deploy the necessary clean-up equipment (The True Tragedy, 2011). Aworawo (2013) also noted that most multinational oil companies that operate in the Niger Delta do so with very little consideration for the environment, which has a very negative impact on economic lives of the people.

Amnesty International believes that the UNEP report on Ogoniland represents the first ever independent scientific study of the impacts of oil pollution in the Niger Delta. The UNEP report revealed the devastating effect of oil exploration on human and the environment. The report also noted that farm yields are lower in areas affected by oil spill. In fact, oil pollution contaminates and the water and streams in local communities. In 
support of this report, we also found that majority of the participants became sick as a result of drinking rain water since they cannot afford water tanks or sink boreholes.

One of the most serious facts brought to light in the UNEP report that is similar to our findings is that the scale of devastation of the drinking water in K-Dere and Bodo has exposed the community members to serious health risks. According to UNEP, oil has seeped below the surface layers of soil and contaminated the ground water in Ogoniland. One of the main reasons for this is the method chosen to return a site to its original state before the spill. This is called "remediation". Amnesty International believes that Shell has caused the remediation method by enhanced natural attenuation (RENA) throughout Ogoniland.

The damage caused by oil spill to the people of K-Dere and Bodo's health is tremendous. UNEP research contains the first data on the health impacts of oil pollution in Ogoniland. The report noted, "petroleum hydrocarbons can enter people's bodies when they breath air, bathe, eat fish, drink water or accidentally eat or touch soil or sediment that is contaminated with oil". The report also referred to raised concentrations of petroleum hydrocarbons cancer and neurotoxicity. The long-term effects are not yet well known, but could include cancer and neurotoxicity. The short-term effect may include dermal exposure which can cause skin redness, cedema, dermatitis, rashes, and blisters; inhalation exposure can lead to red, watery and itchy eyes, coughing, throat irritation, shortness of breath, headache confusion and ingestion of hydrocardon that can lead to nausea and diarrhea.

The damage caused by oil spill to the environment was noted by The African Commission in 2001 following an investigation. The commission stated that oil pollution and environmental degradation has gotten to a level humanly unacceptable. Further, the overall impact of oil spill cannot be determined in money terms because its effect on human beings and the environment is astronomical. However, when quantified, the cost of oil spill to Bodo and K-Dere communities runs into billions of US dollars. For instance, Bodo community through its legal representation demanded compensation of 20 billion naira (US\$129) for losses incurred as a result of oil spill.

\section{CONCLUSION}

After oil was discovered in Ogoni in the late 1950s there were high hopes among the people that their lives would be transformed for the better. However, after fifty years of oil exploration, many of the communities in the Niger Delta, especially K-Dere and Bodo and other communities in Ogoni have remained in poverty. The areas with massive deposit of oil have generated billions in revenue to the country, but a vast majority of people in Ogoniland and other people in Nigeria's oil producing communities are still living in poverty. This poverty has been exacerbated by long-term of oil pollution. Huge oil reserves have been a curse to the people of the area rather than a blessing, this is because the profit from crude oil sale have landed in private pockets rather than used for the development of the oil bearing communities.

Prior to 1993 most communit8ies in Ogoni were simply helpless when oil spills occur since they never knew the impact of such pollution on their environment; they were less likely to react negatively against the company. However, this method of non-reactionary from community members due to oil spills and gas flares changed dramatically in 1993 when Ken Saro Wiwa, under MOSO, launched a campaign against Shell for Shell for environmental devastation of Ogoniland. The campaign against Shell brought an end to gas flaring and oil exploration. After 1993, there was a general awareness amongst communities in Ogoniland of the effect oil pollution and gas flaring on the environment. It is noteworthy that before 1993, oil bearing in Ogoni rarely engages in protest or non violent peaceful resistance against oil multinationals until 1991 when K-Dere instituted legal action against Shell.

\section{Recommendations}

This study recommends that the government should ensure that NOSDRA enforces its regulatory systems by ensuring that oil spills are cleaned up in a timely manner, and by imposing effective penalties on violators of the regulations. The study also recommends a constitution of a Joint Investigation Committee (JIV) consisting of Shell, Government, and Community Representatives. The responsibility of this committee should be to determine the cause of oil spill, volume of oil spilled, the perpetrators, and the amount of compensation to be 
paid to the affected communities. A situation where community members are excluded in the investigation of oil spills only creates a feeling of alienation among host communities. Lastly, there should be routine checks of equipment especially the Trans Niger Pipeline (TNP) because most of the spills occur due to equipment failure.

\section{REFERENCES}

Aworawo, D. (2013) Deprivation and Resistance: Environmental Crisis, Political Action and Conflict Resolution in the Niger Delta since the 1980s. Journal of International and Global Studies.

Adesina, O.S. (2012) The Negative impact of Globalization on Nigeria. International Journal of Humanities and Social Science. Vol. 2

Amnesty International (2011) The True Tragedy: Delays and Failures in Tackling Oil Spills in the Niger Delta.

Atkins, E. (2014) Environmental Conflict: A Misnomer? Environmental climate Change and International Relations.

Barry-Pheby, E.A. 2012) The Growth of Environmental Justice and Environmental Protection in International Law: In the Context of Regulation of the Arctic's Offshore Oil Industry, Sustainable Development Law and Policy, 13(1)

Kadafa, A. Ayuba (2012) Oil and Spillage in the Niger Delta of Nigeria. Civil and Environmental Research 2(3).

Azuakola, S. (2013) Tragic: The June 19 Shell oil spill in Bodo community, Ogoniland" TheScoop

Bob, U. and Bronkhorst, S. (2010) Conflict Sensitive adaptation to Climate Change in Africa (Ed).

Dudafa, U.J. (2017) Niger Delta Crisis and Challenges of Development in the Region. International Journal of Research Education, 10(2) 228-245.

Homer-Dixon, T.F. (1994) Environmental Scarcities and Violent Conflict: Evidence from Cases, International Security, 19(1).

Marx, K. (1971) Manifesto of the Communist Party. Moscow: ProgressPublishers

Nkejiaka, C. (2010). Emergence of Ethnic Militia movements in the Niger Delta Region: From Voice to Armed struggle in the new democratic Nigeria (1999 till Present). Being a dissertation submitted in partial fulfillment of the requirements for the award of Master of Arts degree of the Central European University, Hungary.

Okonta, I. and Douglas, O. (2003) Where Vultures Feast: Shell, Human Rights, and Oil in the Niger Delta, Verso, London.

Udok and Akpan (2017) Gas Flaring in Niger Delta: Problems and Prospect. Global Journal of Politics and Law, 5(1): 16-28)

Uyigue, E. and Agho, M (2007). Coping with Climate Change and Environmental Degradation in the Niger Delta of Southern Nigeria. Community Research and Development Centre Nigeria (CREDC).

Citation: Gbenemene Kpae, Eric. "The Patterns and Trends of Environmental Conflicts in the Niger Delta: A Community Approach". American Research Journal of Humanities and Social Sciences, vol 4, no. 1, 2018, pp. 1-7.

Copyright (c) 2018 Gbenemene Kpae, Eric. This is an open access article distributed under the Creative Commons Attribution License, which permits unrestricted use, distribution, and reproduction in any medium, provided the original work is properly cited. 